\title{
PELATIHAN MODEL BEEF CONCEPT DISERTAI PUSH UP DAN JOGGING LEBIH MENINGKATKAN KETEPATAN SHOOTING FREETHROW BOLA BASKET DARI PADA PELATIHAN MODEL BEEF CONCEPT DISERTAI DUMBEL DAN JOGGING
}

\author{
I Kadek Arya Gangga Permana ${ }^{1}$, Putu Astawa ${ }^{2}$, Desak Made Wihandani ${ }^{3}$, \\ Ketut Tirtayasa ${ }^{4}$, I Made Jawi ${ }^{5}$, Bagus Komang Satriyasa ${ }^{6}$ \\ ${ }^{1}$ Program Studi Magister Fisiologi Keolahragaan Universitas Udayana Denpasar Bali \\ 2,3,4,5,6Fakultas Kedokteran Universitas Udayana Denpasar Bali
}

\begin{abstract}
ABSTRAK
Pendahuluan:Tujuan dari permainan bola basket yaitu suatu kegiatan memasukkan bola kedalam keranjang lawan sebanyak mungkin dan menghalangi lawan untuk menghalangi lawan mencetak angka keranjang sendiri agar. Hal ini menjadi penting karena menentukan poin oleh karena itu untuk meningkatkan kemampuan dan memaksimalkan poin dalam permainan sehingga hal ini perlu dilatih. Tujuan:Penelitian ini bertujuan untuk membandingkan pelatihan model 1 (beef concept disertai push up dan jogging) dan pelatihan model 2 (beef concept disertai dumble dan jogging) terhadap peningkatan ketepatan shooting free throw. Di samping itu, bertujuan untuk mengetahui pelatihan yang lebih meningkatkan ketepatan shooting free throw. Penelitian ini dilakukan terhadap 40 orang siswa SMP Negeri 1 Kuta Selatan yang telah memenuhi criteria inklusi dan eksklusi dimana sampel dipilih dengan acak sederhana. setiap kelompok berjumlah 20 siswa dan pada setiap kelompok diberikan perlakuan yang berbeda selama enam minggu. Kelompok 1 akan diberikan pelatihan model 1 dan Kelompok 2 diberikan pelatihan model 2. Metode: Data dianalisis meggunakan uji $t$ paired yang bertujuan mengetahui perbedaan hasil penelitian sebelum dan setelah pelatihan tersebut dan uji $t$-independent untuk mengetahui perbedaan ketepatan shooting free throw antar kelompok perlakuan.

Hasil: Penelitian ini menunjukkan hasil rerata ketepatan shooting free throwantar kelompok sesudah pelatihan sebesar 3,85 \pm 1,09 pada kelompok 1 dengan pelatihan model 1 dan pada kelompok 2 dengan pelatihan model 2 sebesar 2,90 $\pm 1,12$. Rerata ketepatan shooting free throwpada pelatihan model 1 lebih tinggi dibandingkan dengan pelatihan model 2 yang secara statistik adalah berbeda bermakna dengan hasil nilai $\mathrm{p}=$ 0,010 .

Simpulan: dari hasil penelitian ini disimpulkan bahwa pelatihan model 1 lebih meningkatkan ketepatan shooting free throwdari pada pelatihan model 2, Saran: dalam berlatih disarankan untuk mempergunakan pelatihan model 1 untuk meningkatkan ketepatan shooting free throw.
\end{abstract}

Kata kunci:beef concept, push up, jogging, dumble, shooting free throw. 


\title{
TRAINING MODEL BEEF CONCEPT ACCOMPANIED PUSH UP AND JOGGING WAS MORE INCREASE THE EXACTNESS SHOOTING FREE THROW BASKET BALL THAN TRAINING MODEL BEEF CONCEPT ACCOMPANIED DUMBLE AND JOGGING
}

\begin{abstract}
Introduction: The objective of a basketball game is to insert the ball into the opponent's basket and keep our basket alone so as not to concede the ball. This becomes important because it determines points to improve the ability and maximize points in the game so this needs to be trained. Free throw shots can be done using one hand or two hands. Whereas a free throw is a shot given to a player for committing an offense. This shot is done in the exact position behind the line of free shots in accordance with the rules. Purpose:This study aims to compare training model 1 (beef concept with push up and jogging) and training model 2 (beef concept with dumble and jogging) to improve the accuracy of free throw shooting.

This research was conducted on 40 students of SMP Negeri 1 Kuta Selatan who were chosen in simple random which has fulfilled inclusion and exclusion criteria. The sample was divided into two groups so that each group was 20 people and given different treatment for six weeks. Group 1 was given model 1 training and Group 2 was given a model 2 training. Methods:The data obtained were analyzed by paired t- test to find the difference between before and after training in both groups and t-independent test to find the difference of shooting free throw accuracy between groups both before and after the training. The meaning limit is 0.05. The research design used is experimental design Randomized Pre and Post test Group Design. According to Pocock's (2008) theory, each group consisted of 20 groups of 1 and group 2. All groups were given preliminary tests, between treatment one and two treatment were given concurrent training, then each treatment was observed.

Results:The result showed that the accuracy of free throw shooting between groups after training was $3.85 \pm 1.09$ in group 1 and in group 2 was $2.90 \pm 1.12$. The average accuracy of free throw shooting in training model 1 was higher than with model 2 training which was statistically significantly different with $p=0,010(p<0,05)$.

Conclution:From the results of this study it is concluded that the training of model 1 further improves the accuracy of free throw shooting rather than training model 2, Suggestion: in practice it is suggested to use training model 1 to improve the accuracy of free throw shooting.
\end{abstract}

Keywords: beef concept, push up, jogging, dumble, free throw shooting 


\section{PENDAHULUAN}

Bola basket merupakan permainan bola besar yang dilakukan oleh dua tim putra maupun putri dan masing-masing tim terdapat 5 orang pemain. Permainan ini bertujuan memasukkan bola sebanyak-banyaknya kekeranjang lawan untuk mendapatkan angka atau nilai dan untuk menghalangi lawan mencetak angka atau nilai ${ }^{1}$. Untuk memperoleh suatu gerakan yang baik dan benar harus diberikan penugasan berupa latihan-latihan dasar. Melakukan tembakan dalam permainan bola basket membutuhkan suatu pergerakan yang kompleks seperti pergerakan tungkai, lengan, tubuh dan loncatan vertical atas. Tembakan dipengaruhi oleh jauh dekatnya posisi pemain terhadap ring dan jangkuan lengan pemain. Semakin jauh jarak tembakan tersebut maka pemain tersebut harus melakukan teknik menembak dengan kuat dan tepat. Untuk melakukan sebuah tembakan dibutuhkan kombinasi antara kaki, siku, bahu, punggung, kelentukan pergelangan tangan dan jari-jari tangan. ${ }^{2}$

Permainan bola basket tidak mengenal spesialisasi kemampuan tertentu, oleh karena itu tiap pemain juga harus menguasai teknik Free throw. Dalam melakukan tembakan bebas pada prinsip umumnya ditetapkan guna untuk memperoleh sebuah ketepatan yaitu mencetak poin. Karena ketika terjadi pelanggaran dengan hukuman tembakan bebas maka yang melakukannya harus pemain yang mengalami pelanggaran oleh pihak lawan. Melakukan ShootingFree throw menggunakan bola basket ukuran 6 masih terlalu berat, akibatnya sulit untuk memasukkan bola ke dalam ring atau bahkan tidak sampai menyentuh ring. Oleh karena itu, banyak siswa yang gagal melakukan Shooting free throwkarena tidak kuatnya otot lengan pada saat melakukan gerakan shooting. Untuk itu dalam kegiatan ekstrakurikuler bola basket perlu melakukan latihan fisik untuk melatih kekuatan, agar siswa pemula dapat lebih mudah dalam melakukan teknik Shooting.

Kegiatan ekstrakurikuler khususnya ekstrakurikuler bola basket di SMP Negeri 1 Kuta Selatan yang dilakukan oleh anak-anak pemula khususnya putri masih kurang berkembang dari segi strength otot lengan dan endurancekekuatan dalam melakukan Shooting free throw. Untuk itu pelatih mencoba menggunakan teknik push-up dan dumbel untuk meningkatkan kekuatan strength otot lengan serta jogginguntuk meningkatkan daya tahan fisik kepada siswa pemula khususnya putri dalam kegiatan ekstrakurikuler bola basket.Peneliti meneliti 2 model pelatihan pada siswa pemula putri yang ada di SMP Negeri 1 Kuta Selatan untuk meningkatkan prestasi bola basket dimana model 1 yaitu pelatihan beef concept disertai push up dan jogging dan model 2 yaitu pelatihan beef concept disertai dumbel dan jogging.

\section{METODE PENELITIAN}

\section{A. Rancangan Penelitian}

Rancangan penelitiannya menggunakan penelitian eksperimental dimana masing kelompok terdapat 20 siswa pada kelompok pertama dan kelompok kedua. Diberikan tes awal pada kedua kelompok, dimana masingmasing kelompok diberikan pelatihan secara bersama-sama. Kemudian pada masing-masing kelompok perlakuan dilakukan observasi 


\section{B. Tempat dan Waktu Penelitian}

Lapangan Basket PNB Jimbaran menjadi tempat dilaksanakannya penelitian ini. Waktu pelatihan dilakukan selama 6 minggu terhitung dari bulan Agustus sampai Oktober 2017, pengambilan data dilakukan pada jam 15.00 - 17.00 Wita pada sore hari.

\section{Populasi dan Sampel}

Populasi target: Siswa pemula putri SMPN 1 Kuta Selatan.Populasi target pada penelitian tersebut yaitu semua siswa pemula putri ekstrakurikuler bola basket SMPN 1 Kuta Selatan. Populasi terjangkau: Siswa pemula putri ekstrakurikuler bola basket SMPN 1 Kuta Selatan. Sampel diperoleh dalam penelitian tersebut yang telah memenuhi kreteria.

\section{Teknik Pengambilan Sampel}

Berdasarkan kriteria di atas pemilihan sejumlah sampel dari seluruh populasi dengan menggunakan cara acak sederhana (simple random sampling). Dimana jumlah pada masing kelompok adalah 20 siswa kemudian kelompok 1 akan mendapat perlakuan model 1 sedangkan kelompok 2 akan menerima perlakuan model 2.

\section{E. Prosedur Penelitian}

Persiapan dan pengurusan surat ijin penelitian, dan menghadap kepada kepala sekolah SMPN 1 Kuta Selatan, memberikan penjelasan mengenai penelitian, yang disepakati bahwa yang akan dipergunakan sebagai sampel penelitian adalah siswa SMPN 1 Kuta Selatan. Persiapan peralatan dan mengurus alat - alat yang akan dipergunakan dalam penelitian dan tempat serta tenaga pembantu saat penelitian. Semua siswa yang memenuhi kriteria kemudian diundi secara acak sehingga memperoleh sampel.

\section{HASIL PENELITIAN}

\section{Karakteristik Subjek Penelitian}

Karakteristik subjek penelitian meliputi: umur (Dimana semua responden berumur 13 tahun), tinggi badan, berat badan. Hasil deskripsi karakteristik subjek penelitian disajikan dalam Tabel 5.1

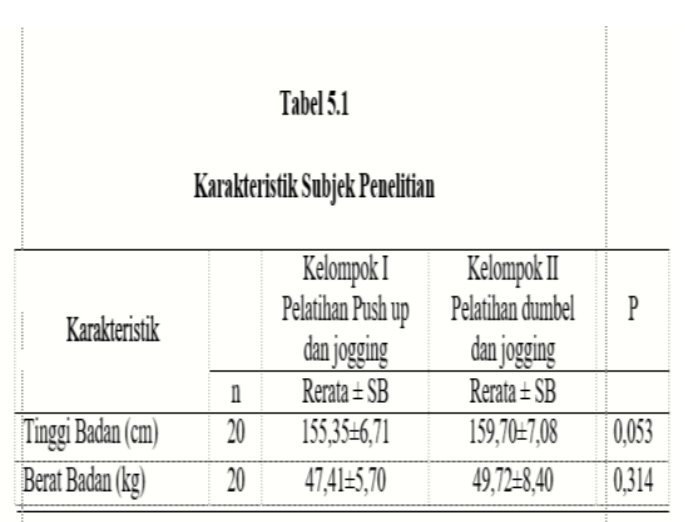

\section{Uji Normalitas dan Homogenitas}

Untuk mencari data yang berdistribusi terhadap sampel penelitian dilakukan uji Saphiro Wilk Test untuk mencari normalitas data pada kedua kelompok perlakuan sebelum dan setelah pelatihan, dimana variable yang diuji yaitu ketepatan. Dimana hasilnya disajikan pada tabel dibawah.

\begin{tabular}{|c|c|c|c|}
\hline \multicolumn{4}{|c|}{\begin{tabular}{|c|} 
Tabel 5.3 \\
Hasil Uji Normalitas dan Homogenitas Data Hasil Kekuatan Otot Lengan \\
dan Shooting Free Throw Sebelum dan Sesudah Pelatihan
\end{tabular}} \\
\hline \multirow{2}{*}{ Hasil Analisis } & \multicolumn{2}{|c|}{ (p) Uji Normalitas (Shapiro Wilk Test) } & \multirow{2}{*}{$\begin{array}{l}\text { (p) Uji Homogenita } \\
\text { (Levene Test) }\end{array}$} \\
\hline & Kelompok I & Kelompok II & \\
\hline $\begin{array}{l}\text { Keluatan otot } \\
\text { Sebelum Pelatihan }\end{array}$ & 0,078 & 0,143 & 0,393 \\
\hline $\begin{array}{l}\text { Kekuatan otot } \\
\text { Sesudah Pelatihan }\end{array}$ & 0,171 & 0,071 & 0,871 \\
\hline $\begin{array}{l}\text { Shooting free throw } \\
\text { sebelum pelatihan }\end{array}$ & 0,121 & 0,055 & 0,722 \\
\hline $\begin{array}{l}\text { Shooting free throw } \\
\text { setelah pelatihan }\end{array}$ & 0,078 & 0,117 & 0,836 \\
\hline
\end{tabular}

Berdasarkan tabel diatas menunjukkan data yang dianalisis menggunakan uji normalitas dan homogenitas didapatkan 
hasil nilai (p) lebih tinggi dari 0,05 pada masing-masing kelompok perlakuan sebelum dan setelah perlakuan yaitu kekuatan otot lengan dan ketepatan shooting free throw sedangkan uji homogenitas digunakan uji Levene Test hasil yang diperoleh data homogen.

\section{Uji Beda Kekuatan Otot Lengan Antar Kelompok}

Analisis data yang dipergunakan untuk membandingkan hasil rerata kekuatan otot lengan antar kelompok perlakuan dengan menggunakan uji beda dimana pada kelompok I diberikan latihan beef concept disertai latihan push up dan jogging dan kelompok II diberikan latihan beef concept disertai latihan dumbel dan jogging. Dimana untuk menganalisis data tersebut menggunakan uji t-independent (tidak berpasangan). Hasil data tersebut dapat dilihat pada tabel di bawah ini.

\begin{tabular}{|c|c|c|c|c|c|}
\hline \multicolumn{6}{|c|}{$\begin{array}{l}\text { Tabel } 5.4 \\
\text { erata Hasil Kekutatan Otot Lengan Antar }\end{array}$} \\
\hline $\begin{array}{l}\text { Hasil } \\
\text { kekuatan }\end{array}$ & $\mathrm{N}$ & $\begin{array}{c}\text { Kelompok I } \\
\text { Push up }\end{array}$ & $\begin{array}{c}\text { Kelompok II } \\
\text { dumbel }\end{array}$ & $t$ & $\mathrm{P}$ \\
\hline otot lengan & & Rerata $\pm S B$ & Rerata $\pm S B$ & & \\
\hline $\begin{array}{l}\text { Sebelum } \\
\text { pelatihan }\end{array}$ & 20 & $22,15 \pm 1,81$ & $21,25 \pm 2,45$ & 1,321 & 0,194 \\
\hline $\begin{array}{l}\text { Sesudah } \\
\text { pelatihan }\end{array}$ & 20 & $31,55 \pm 2,58$ & $27,85 \pm 2,52$ & 4,585 & 0,000 \\
\hline
\end{tabular}

Tabel diatas mendeskripsikan bahwa hasil rerata kekuatan otot lengan sebelum dilakukan pelatihan antara kelompok pertama dan kelompok kedua pelatihan sama - sama lebih besar dari 0,05 . Diamana hasil dari kekuatan otot lengan tidak ada berbeda. Setelah diberikan pelatihan terdapat perbedaan bermakna.

\section{Hasil Uji Beda Shooting Free ThrowAntar Kelompok}

Untuk mengetahui perbandingan rerata shooting free throw menggunakan uji beda t-independent (tidak berpasangan) dimana hasilnya dapat disajikan pada Tabel 5.5 di bawah ini.

\begin{tabular}{|c|c|c|c|c|c|}
\hline & & $\begin{array}{c}\text { eda Rerata H } \\
\text { Kelomp }\end{array}$ & $\begin{array}{l}5.5 \\
\text { ting Free Thr } \\
\text { ihan }\end{array}$ & ntar & \\
\hline $\begin{array}{l}\text { Hasil } \\
\text { shooting }\end{array}$ & $\mathrm{n}$ & $\begin{array}{l}\text { Kelompok I } \\
\text { Rerata } \pm \text { SB }\end{array}$ & $\begin{array}{l}\text { Kelompok II } \\
\text { Rerata } \pm \text { SB }\end{array}$ & $\mathrm{t}$ & $P$ \\
\hline $\begin{array}{l}\text { Sebelum } \\
\text { pelatihan }\end{array}$ & 20 & $2,15 \pm 1,27$ & $1,75 \pm 1,12$ & 1,058 & 0,297 \\
\hline $\begin{array}{l}\text { Sesudah } \\
\text { pelatihan }\end{array}$ & 20 & $3,85 \pm 1,09$ & $2,90 \pm 1,12$ & 2,720 & 0,010 \\
\hline
\end{tabular}

Tabel 5.5 mendeskripsikan bahwa rerata dari hasil shooting free throw sebelum pelatihan antara kelompok pertama dan kelompok kedua memiliki nilai $\mathrm{p}$ lebih besar dari batas kemaknaan. Dimana hasilnya sebelum pelatihan antar kelompok tidak berbeda bermakna (sebanding). Setelah perlakuan nilai $\mathrm{p}$ lebih kecil dari batas kemaknaan, dimana hasilnya dari masingn - masing kelompok berbeda bermakna.

\section{PEMBAHASAN}

\section{Karakteristik Subjek Penelitian}

Berdasarkan dari data pada Tabel 5.1 rerata tinggi badan subjek penelitian kelompok Ipelatihan model 1 (beef concept disertai latihan push up dan jogging) adalah 155,35 $\pm 6,71 \mathrm{~cm}$ dan kelompok II pelatihan model 2 (beef concept disertai latihan dumbeldan jogging) $159,70 \pm 7,08 \mathrm{~cm}$. Rerata berat badan subjek penelitian pada kelompok I adalah $47,41 \pm 5,70 \mathrm{~kg}$ dan pada kelompok II 49,72 $\pm 8,40 \mathrm{~kg}$. Data tersebut menunjukkan bahwa subjek penelitian pada kelompok pertama dan kelompok kedua pelatihan memiliki rerata tinggi dan berat badan yang tidak jauh berbeda, sehingga hasil dari penelitian tidak akan terpengaruh. Faktor yang mempengaruhi kecepatan adalah tinggi dan berat. $^{3}$ Dengan demikian tinggi dan berat badan sangat 
berpengaruh pada ketepatan shooting free throw yang selanjutnya tentu akan berpengaruh pada jarak tembakan.

\section{Karakteristik Penelitian \\ Lingkungan}

Penelitian dilakukan di lapangan bola basket PNB Jimbaran dengan rentangan suhu kering berkisar antara $27,1^{\circ} \mathrm{C}-30{ }^{\circ} \mathrm{C}$ dan suhu basah $24,7{ }^{\circ} \mathrm{C}$ s/d $26{ }^{\circ} \mathrm{C}$, sedangkan rentangan kelembaban relatif berkisar antara $65 \%$ s/d 78\%. Suhu udara dan kelembaban relatif tempat penelitian berada pada batas normal. Lingkungan pelatihan merupakan faktor penunjang terlaksananya penelitian, karena kenyamanan proses pelatihan sangat dipengaruhi oleh suhu basah dan kering.

\section{Pengaruh Pelatihan Model 1 (Beef Concept Disertai Latihan Push up dan Jogging)Terhadap Peningkatan Ketepatan Shooting Free Throw}

Berdasarkan hasil tes ketepatan shooting free throw dari pre test dan post test didapatkan rerata hasil shooting free throw sebelum pelatihan pada kelompok I pelatihan model 1 (beef concept disertai latihan push up dan jogging) adalah 2,15 $\pm 1,27$ dan sesudah pelatihan 3,85 $\pm 1,09$. Peningkatan yang terjadi terhadap hasil ketepatan shooting free throw sebelum dan setelah pelatihan pada kelompok I yaitu 1,70 .

Pelatihan dilakukan tiga kali dalam seminggu dan dilakukan selama 6 minggu dengan beban progresif. Dua minggu pertama atau enam kali pelatihan diberikan beban 10 repetisi 3 set dan dua minggu berikutnya atau enam kali diberikan beban 15 repetisi 3 set dan dua minggu terakhir diberikan beban 20 repetisi 3 set dengan waktu istirahat 1-2 menit tiap setnya.Pelatihan yang diberikan secara teratur selama enam sampai dengan delapan minggu akan memberikanefek yang nyata karena kondisi tubuh subjek penelitianmulai beradaptasi dengan pola pelatihan yang telah dilakukan dapat memperbaiki sistem dalam organ tubuh sehingga performa fisik menjadi maksimal seperti pada model 1 otot yg terbentuk mulai dari otot lengan, otot bahu, otot dada dan otot perut. Pelatihan yang diberikan sebanyak 3x dalam 1 minggu akan dapat meningkatkan hasil maksimal $^{4}$.

Pelatihan beban yang
dilaksanakan dengan terukur dan berkesinambungan dapat terjadi hipertropi kepada jaringan otot, hal ini terjadi karena banyaknya myofibril, kepadatan pada pembuluh darah kapiler, saraf, tendon, ligamendan jumlah kontraktil terutama protein kontaraktil miosin meningkat secara proposional. ${ }^{5}$ Semakin sering pola latihan yang dilaksanakan maka semakin berpengaruh terhadap pembesaran pada fibril otot, ini dapat meningkatan kekuatan pada otot $^{6}$. Dampak dari pelatihan ini adalah meningkatkan kekuatan otot yang dilatih serta memberikan efek terhadap bentuk tubuh yang mulai terlihat kuat dan terbentuk seiring berjalannya pelatihan.

Hasil yang mendukung penelitian ini adalah dari Rudiansyah dimana terjadi peningkatan ketepatan ${ }^{7}$.

Melakukan gerakan free throw membutuhkan skill, fokus dan percaya pada diri sendiri. Kebiasaan dalam melakukan follow throw akan membantu konsentrasi dalam melakukan tembakan. Untuk meningkatkan akurasi tembakan, bersikaplah tenang dan percaya diri saat menuju ke garis free throw. Untuk meningkatkan tembakan dengan melakukan latihan tembakan bebas sesering mungkin ${ }^{8}$. 
4. Pengaruh Pelatihan Model 2 (Beef Concept Disertai Latihan Dumbel dan Jogging) Terhadap Peningkatan Ketepatan Shooting Free Throw

Berdasarkan dari hasil tes ketepatan shooting free throw didapatkan rerata ketepatan shooting sebelum pelatihan pada kelompok II pelatihan model 2 (beef concept disertai latihan dumbel dan jogging) adalah $1,75 \pm 1,12$ dan sesudah pelatihan $2,90 \pm 1,12$. Peningkatan yang didapatkan terhadap hasil shooting free throw sebesar 1,15.

Pelatihan dilakukan sebanyak tiga kali seminggu dan dilaksanakan selama enam minggu dengan beban progresif. dua minggu pertama atau enam kali pelatihan diberikan beban dumbel seberat $2 \mathrm{~kg} 10$ repetisi 3 set dan dua minggu berikutnya atau enamkali diberikan beban dumbel 3 kg10 repetisi 3 set dan dua minggu terakhir diberikan beban dumbel $4 \mathrm{~kg}$ 10 repetisi 3 set dengan waktu istirahat 1-2 menit tiap setnya.Pelatihan yang diberikan secara teratur selama enam sampai delapan minggu bisa memberikan efek yang signifikan karena tubuh sudah bisa beradaptasi terhadap pelatihan yang dilakukan sehingga penampilan pada fisik akan optimal $^{9}$. Semakin sering pelatihan yang dilakukan maka dapat menyebabkan adanya peningkatan kekuatan otot. ${ }^{10}$

\section{Perbedaan Pengaruh Pelatihan} Model 1 (Beef Concept Disertai Latihan Push up dan Jogging) dengan Pelatihan Model 2 (Beef Concept Disertai Dumbel dan Jogging) Terhadap Peningkatan Ketepatan Shooting Free Throw

Perbedaan hasil shooting free throwsebelum pelatihan antar kedua kelompok pelatihan yaitu antara kelompok I pelatihan model 1(beef concept disertai latihan push up dan jogging)dankelompok II pelatihan model 2 (beef concept disertai latihan dumbel dan jogging)yang dianalisis dengan uji t-independen test, hasil analisis menunjukkan nilai $\mathrm{p}=0,297$. Hal ini menunjukkan bahwa hasil shooting free throw sebelum pelatihan antara kedua kelompok tidak ada perbedaan dengan demikian hasil shooting free throw pada kedua kelompok perlakuan adalah sebanding dan hasil shooting free throwsesudah pelatihan menunjukkan nilai $\mathrm{p}=0,010$. Hal ini menunjukan bahwa shooting free throw sesudah pelatihan antara kedua kelompok berbeda.

Peningkatan hasil shooting free throwkelompok I lebih besar jika dibandingkan dengan kelompok II dilihat dari nilai rerata hasil setelah pelatihan pada Tabel 5.5. Nilai rerata shooting free throwkelompok I $3,85 \pm 1,09$ meningkat 1,70 atau 79,07 \% dari tes awal dan kelompok II2,90 $\pm 1,12$ meningkat 1,15 atau $65,71 \%$ dari tes awal, nilai ini menunjukkan terdapat perbedaan hasil peningkatan shooting free throw.

Perbedaan hasil yang terjadi disebabkan oleh perbedaan jenis gerakan yang diberikan selama pelatihan. Perbedaan beban tubuh dalam proses latihan dapat meningkatkan adaptasi fisiologi pada tubuh terhadap latihan yang dilakukan secara berulang sehingga terjadi kontraksi dan gerak dorong semakin maksimal ${ }^{11}$.

Berdasarkan hasil yang didapatkan bahwa pelatihan model 1(beef concept disertai latihan push up dan jogging) dan pelatihan model 2(beef concept disertai latihan dumbel dan jogging) sama-sama meningkatkan shooting free throw tetapi berdasarkan hasil yang didapatkan pelatihan model 1(beef concept disertai latihan push up dan jogging) lebih baik dari pelatihan 
model 2 (beef concept disertai latihan dumbel dan jogging). Nilai rerata shooting free throwkelompok I $3,85 \pm 1,09$ meningkat 1,70 atau 79,07 \% dari tes awal dan kelompok II2,90 $\pm 1,12$ meningkat 1,15 atau $65,71 \%$ dari tes awal, nilai ini menunjukkan terdapat perbedaan hasil peningkatan shooting free throw. Jadi disarankan menggunakan pelatihan model 1 (beef concept disertai latihan push up dan jogging) karena lebih banyak otot tubuh yang terlatih seperti otot perut, otot dada,otot bahu,dan otot lengan daripada pelatihan model 2 (beef concept disertai latihan dumbeldan jogging) dimana hanya melatih kekuatan otot lengan sehingga pelatihan model 1 meningkatkan hasil yang lebih baik untuk meningkatkan ketepatan shooting free throw.

\section{SIMPULAN}

Bersadarkan uraian dan hasil penelitian, dapat ditarik kesimpulkan yaitu :

1. Pelatihan model beef concept disertai latihan push up dan jogging meningkatkan ketepatan shooting free throw.

2. Pelatihan model beef concept disertai latihan dumbel dan jogging meningkatkan ketepatan shooting free throw.

3. Pelatihan model beef concept disertai latihan push up dan jogging lebih meningkatkan ketepatan shooting free throw daripada pelatihan model beef concept disertai latihan dumbel dan joggingpada siswa putri peserta ekstrakurikuler bola basket SMP Negeri 1 Kuta Selatan.

\section{DAFTAR PUSTAKA}

1. Ambler, 2011. Petunjuk untuk Pelatihan dan Pemain Bola Basket.Bandung: CV.Pionir

2. Wissel, Hal. 2000. Bola Basket Dilengkapi Dengan Program Pemahiran Teknik dan Taktik. Jakarta: PT. Rajagrafindo Persada.

3. Widiantari. 2015. Yang berjudul "Pengaruh Latihan Sprint Training dan Kelincahan terhadap Peningkatan Daya Tahan Anaerobik Peserta Ekstrakurikuler Bola Basket SMK Negeri 3 Yogyakarta. Skripsi. FIK UNY.

4. Nala, N. 2011. Prinsip Pelatihan Fisik Olahraga. Denpasar: Udayana University Press.

5. Prananta, C. A. 2014. "Perbandingan Jump Shoot Dengan Awalan dan Tanpa Awalan Terhadap Peningkatan Ketepatan Jump Shooting Dalam Permainan Bola Basket" (Jurnal Tesis). Denpasar: Universitas Udayana.

6. Sudarsono, S. 2011. Penyusunan Program Pelatihan Berbeban untuk Meningkatkan Kekuatan. Jurnal Ilmiah SPIRIT, ISSN:1411-8319 No

7. Rudyansyah dkk. Jurnal berjudul "Upaya Meningkatkan shooting Free Throw Permainan Bola Basket dengan Metode Strength". Skripsi. STKIP Melawi.

8. Triyono. 2003. Fundamental Basic For Player BasketBall. Semarang: PB. SAHABAT Semarang

9. Nala, N. 2002. Prinsip Pelatihan Fisik Olahraga. Denpasar: Komite Olahraga Nasional Indonesia Daerah Bali.

10. Kanca, Budi. 2004. Peningkatan \& Pembinaan Kekuatan Kondisi Fisik dalam Olahraga. Jakarta, Departemen Pendidikan dan Kebudayaan Direktorat Jenderal Pendidikan Tinggi. 
11. Sajoto. 2002. Peningkatan dan Pembinaan Kekuatan Kondisi Fisik. Semarang: Effar dan Dahara Prize. P. 70-98. 